\title{
Penerapan Tema 'Explore and Find Serenity' pada Perancangan Interior Ganara Art School
}

\author{
Jl. Scientia Boulevard, Tangerang, Banten \\ Desy Lestary', Eddy Supriyatna Marizar², Maitri Widya Mutiara ${ }^{3}$ \\ Fakultas Seni Rupa dan Desain, Universitas Tarumanagara ${ }^{123}$ \\ desy.615140093@stu.untar.ac.id, eddym@fsrd.untar.ac.id, maitrim@fsrd.untar.ac.id
}

\begin{abstract}
Seiring dengan perkembangan zaman, seni bukan hanya dinikmati sebagai sarana hiburan, hobi dan kesenangan saja, namun juga menjadi bagian dari Pendidikan formal dalam bentuk pendidikan lanjutan. Ganara Art School merupakan salah satu sekolah non formal berbasis seni yang terletak di Jakarta. Perancangan interior dengan konsep tema "Explore and find Serenity" merupakan konsep yang menampilkan sisi kemurnian dari seni rupa kontemporer dengan menggunakan permainan bentuk berupa prototipe dari bentuk-bentuk yang terinspirasi dari alam seperti pohon, lembah dan goa yang. Bentuk-bentuk tersebut kemudian diimplementasikan ke dalam elemen interior dengan gaya yang modern. Penerapan konsep tematik yang didukung dengan permainan material dan warna natural yang minim bertujuan untuk tidak menginterupsi karya seni yang ada didalam ruangan tersebut sehingga menciptakan desain ruang yang imajinatif, nyaman dan dapat mendukung proses kreativitas, imajinasi dan minat berkarya dalam diri seseorang. Perancangan dilakukan melalui proses desain yang diawali dengan peninjauan studi pustaka mengenai sekolah seni dalam hal tata ruang, ergonomi. Proses selanjutnya adalah menganalisis aktifitas yang diwadahi dan fasilitas yang dibutuhkan serta mengimplementasikannya menjadi sebuah rancangan desain interior yang sesuai dengan citra lembaga serta memenuhi kebutuhan pengguna ruang.
\end{abstract}

Kata kunci: Desain Interior, Imajinasi, Seni, Sekolah Seni Ganara

\section{PENDAHULUAN}

Bidang seni juga merupakan salah satu bidang yang berkembang pesat seiring dengan berjalannya waktu. Sebagian besar masyarakat menikmati seni tidak hanya sebagai hobi atau kesenangan saja, namun tertarik untuk mempelajarinya, sehingga banyak yang mendalami bidang seni sebagai pendidikan lanjutan dari pendidikan formal. Seni rupa khususnya seni rupa murni merupakan salah satu bagian bidang seni hiburan yang cukup banyak diminati oleh masyarakat karena tidak terbatas oleh kalangan usia dalam hal menikmati dan mempelajari seni tersebut.
Ganara Art School merupakan salah satu sekolah non formal berbasis seni yang terletak di Jakarta dan sudah berdiri sejak tahun 2013 silam. Secara garis besar Ganara Art School memiliki dua branding yaitu Ganara Art Studio untuk anak-anak berumur 1-12 tahun dan Ganara Art Space untuk kalangan berusia di atas 12 tahun serta sarana dan prasarana bagi masyarakat seperti ruang pameran dan ruang workshop. Oleh karena itu, perancangan interior menjadi salah satu perhatian penting karena dapat membangun dan mendukung proses imajinasi, kreativitas dan minat berkarya dalam diri seseorang. Maka racangan harus dilengkapi dengan 
area berkreasi yang nyaman dan menyenangkan serta bersifat edukatif.

Pendidikan seni rupa menurut Sofyan Salam (2001) adalah sebagai sarana untuk membentuk kepribadian (cipta, rasa, karsa) secara utuh dan bermakna, melalui kegiatan praktek berolah seni rupa sesuai dengan potensi maupun kompetensi pribadinya dan kepekaan daya apresiasinya. Fungsi dari pendidikan seni menurut Tumurang (2006:31) adalah sebagai media ekspresi, komunikasi, bermain, pengembangan bakat, pengembangan kemampuan berpikir dan memperoleh pengalaman estetis. Seni berdasarkan bentuk dan mediumnya di klasifikasikan dalam lima kelompok, yaitu seni rupa yang terdiri dari seni rupa murni dan terapan, seni sastra, seni musik, seni tari dan seni teater (Nurhadiat, 2004:4). Didalam buku School Buildings for Afro-Asian Countries oleh Central Building Research Institute Roorkee (1986) pembagian ruang dalam sekolah seni dibagi menjadi tiga area, yaitu area belajar mengajar yang meliputi ruang kelas, ruang studio, perpustakaan, area administratif meliputi kantor dan ruang administrasi dan area servis.

Tujuan dari perancangan interior Ganara Art School adalah menciptakan rancangan ruang yang dapat memenuhi kebutuhan aktivitas dan fasilitas sehingga dapat mendukung sistem pembelajaran berjalan dengan efektif dan efisien. Merancang suatu ruang berkreasi yang nyaman dan menyenangkan sehingga dapat mengembangkan imajinasi dan kreatifitas pengguna ruang serta sesuai dengan citra lembaga.

\section{METODE}

Metode yang digunakan untuk mendapatkan solusi desain adalah proses desain sesuai paparan dari Kilmer (Kilmer \& Kilmer, 2014) yaitu:

1. Tahap programming, yang meliputi:

a. Pengumpulan data melalui studi literatur tentang sekolah seni dan studi lapangan ke lokasi untuk mengumpulkan data dari wawancara, observasi dan dokumentasi.

b. Identifikasi masalah, meliputi aspek manusia, lingkungan, bangunan dan ruang.

c. Analisa terhadap proyek, meliputi aspek manusia, lingkungan, bangunan dan ruang.

d. Konsep yaitu evaluasi dan kesimpulan yang diperoleh dan dikembangkan dalam bentuk konsep perancangan diwujudkan dalam betuk 3 dimensional. 
2. Tahap Space Planning, meliputi layout plan, gambar tampak potongan, floor plan, ceiling plan, electrical plan, detail konstruksi interior, detail rancangan furnitur dan gambar perspektif.

3. Tahap Keputusan Desain, meliputi denah berwarna, tampak potongan berwarna, perspektif berwarna, skema material dan warna, skema furnitur dan maket.

\section{HASIL DAN PEMBAHASAN}

\section{A. Profil Lembaga}

Ganara adalah sebuah lembaga non formal yang memfasilitasi dan mewadahi masyarakat yang memiliki antusias dalam bidang seni untuk berkarya dan mendapatkan pendidikan seni. Ganara telah berdiri sejak tahun 2013.

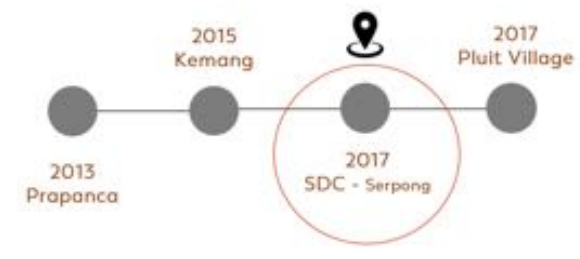

Gambar 1. Timeline Ganara (Sumber: Desy Lestary,2018)

Ganara memiliki beberapa klasifikasi kelas seni, diantaranya adalah sebagai berikut:

1. Ganara Art Studio, untuk anak berusia 1,5-12 tahun yang meliputi kelas menggambar, melukis dan memasak.
2. Ganara Art Space, diperuntukkan untuk remaja hingga dewasa yang meluputi kelas menggambar dan melukis.

3. Ganara Pottery, kelas studio yang mengajarkan teknik membuat tembikar dengan tanah liat dan terbagi menjadi dua kelas yaitu untuk anak-anak dan dewasa.

4. Ganara Digital, diperuntukkan untuk remaja hingga dewasa meliputi kelas studio fotografi dan digital editing.

5. Ganara Film \& Music, mempelajari penulisan naskah, pembuatan storyboard, shooting editing film dan penulisan musik digital, diperuntukkan untuk remaja hingga dewasa.

6. Ganara Art Gallery, berupa ruang pameran seni untuk seniman muda dan murid bimbingan Ganara serta terbuka untuk umum.

7. Ganara Event, merupakan rangkaian acara atau workshop yang di adakan oleh Ganara, pada waktu, tempat dan special event.

8. Ganara Goddies, adalah tempat perbelanjaan yang menjual aksesoris dan hasil buah tangan Ganara.

9. Mari Berbagi Seni, merupakan gerakan berbagi seni oleh Ganara Art School.

Data Pengguna Ganara dapat diklasifikasi menjadi: 


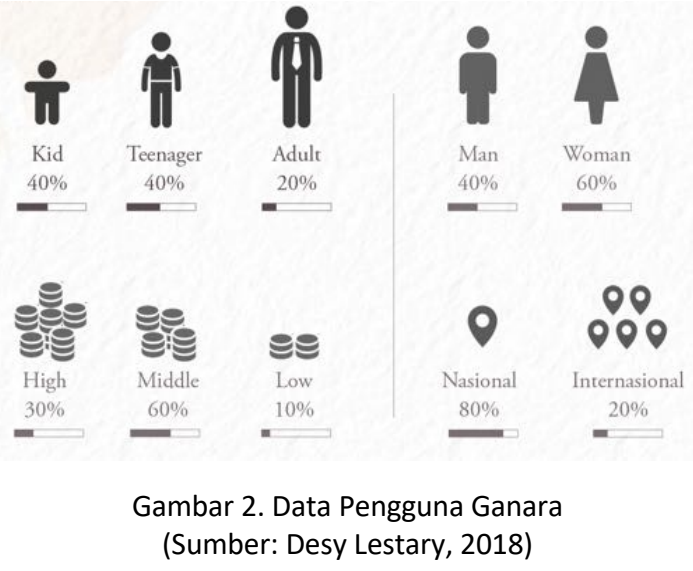

Ganara memiliki total 45 personil kerja dengan struktur organisasi sebagai berikut:

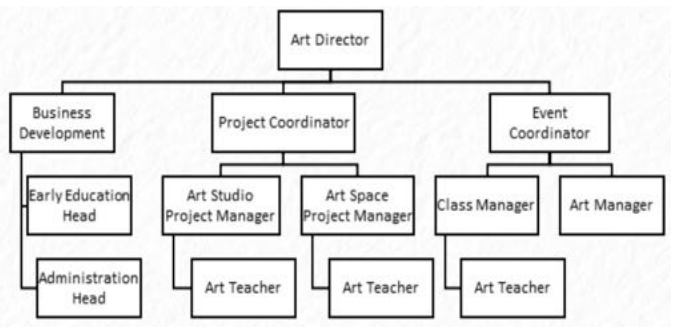

Gambar 3. Struktur Organisasi Ganara (Sumber: www.ganara.id)

Sarana dan prasarana yang terdapat didalam Ganara meliputi:

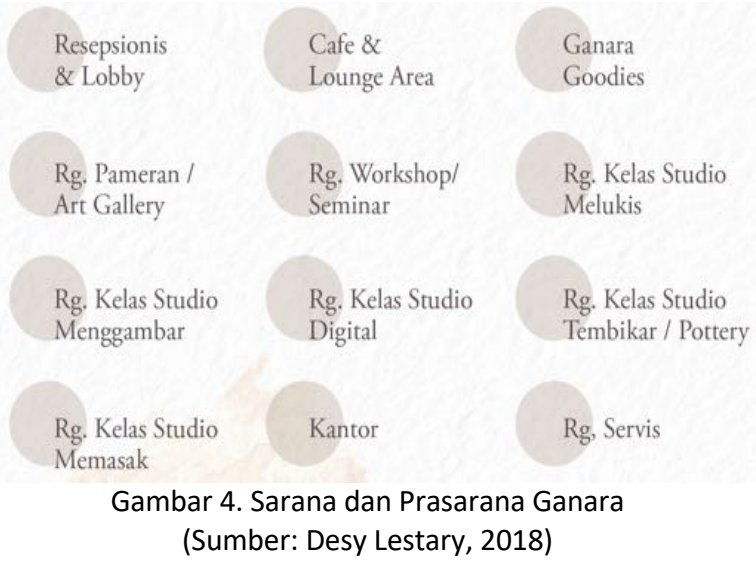

Tata alur dan hubungan kerja antara pengunjung serta karyawan yang berada di dalam Ganara Art School adalah sebagai berikut: $\square$ Skema aktivitas murid / peserta
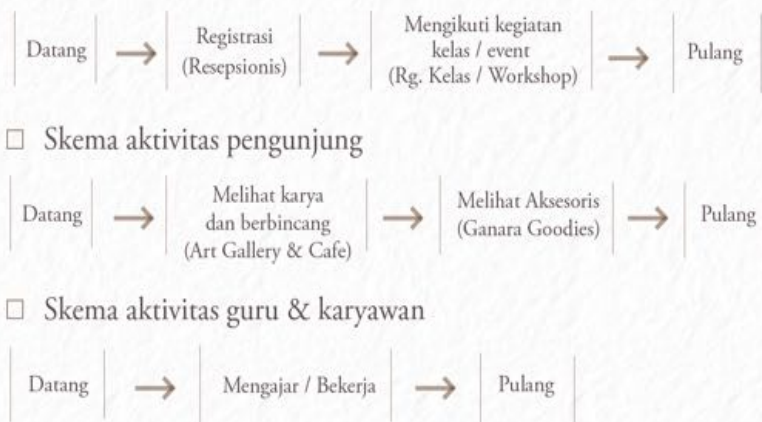

Gambar 5. Tata Alur dan Hubungan Kerja Ganara (Sumber: Desy Lestary, 2018)

B. Konsep Zoning, Grouping, Layout dan Pola Sirkulasi

Melalui analisis data yang ada, berikut adalah hubungan kedekatan antar ruang pada perancangan Ganara Art School.

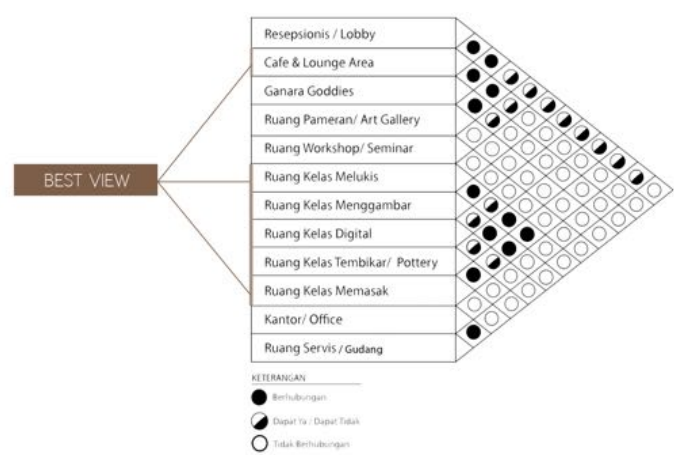

Gambar 6. Matriks Perancangan Ganara (Sumber: Desy Lestary, 2018)

Konsep zoning pada Ganara memiliki 4 area atau zona, meliputi zona publik yaitu area atau zona umum yang dapat dimasuki oleh pengunjung tanpa persyaratan tertentu, zona semi privat yaitu area yang dapat dimasuki oleh pengunjung, murid maupun tamu yang mengikuti kelas, workshop atau event yang diadakan oleh Ganara, zona privat untuk guru serta staff yang bekerja di Ganara dan zona service yaitu zona untuk cleaning service dan 
security. Berikut adalah zoning pada perancangan Ganara Art School.

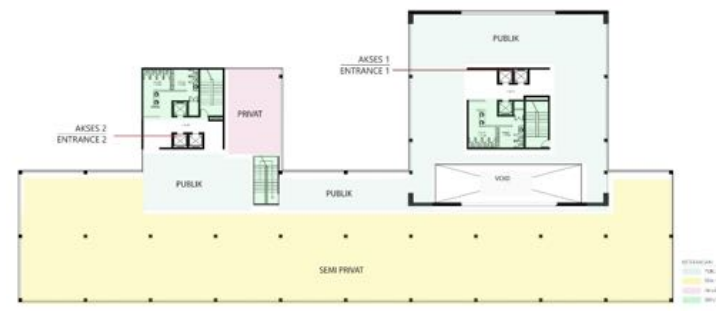

Gambar 7. Zoning Perancangan Ganara

(Sumber: Desy Lestary, 2018)

Melalui pembagian zoning di atas, berikut ini adalah pembagian grouping pada perancangan Ganara Art School.

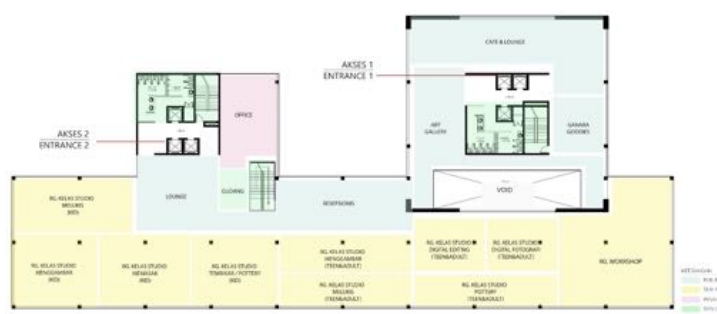

Gambar 8. Grouping Perancangan Ganara (Sumber: Desy Lestary, 2018)

Terdapat dua pola sirkulasi pada perancangan Ganara Art School, yaitu horizontal dan vertikal. Konsep pola sirkulasi horizontal bersifat radial, dengan tujuan pengguna dapat mengelilingi dan bereksplorasi pada setiap area baik publik dan semi privat secara mudah.

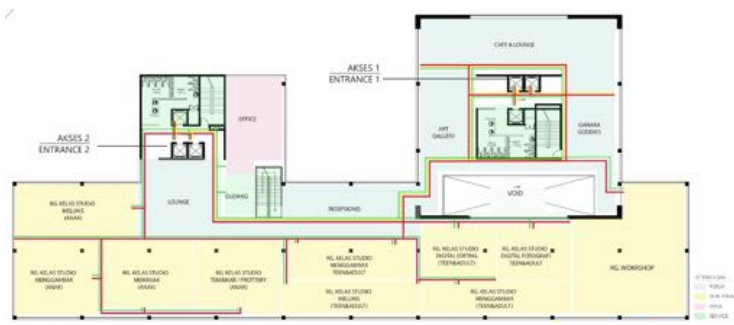

Gambar 9. Pola Sirkulasi Perancangan Ganara (Sumber: Desy Lestary, 2018)

Konsep layout pada perancangan Ganara dititik beratkan pada permainan bentuk yang disesuaikan dengan tema yang diterapkan yaitu Explore and find Serenity. Terdapat beberapa permainan leveling floor pada area-area tertentu untuk memberikan kesan dinamis sehingga pengunjung tidak akan merasa bosan. Layout uang bersifat open space baik pada area publik maupun semi privat, sehingga pengunjung dapat melihat aktivitas yang sedang berlangsung didalam kelas dengan pembatas antar area berupa sekat-sekat dan leveling floor.

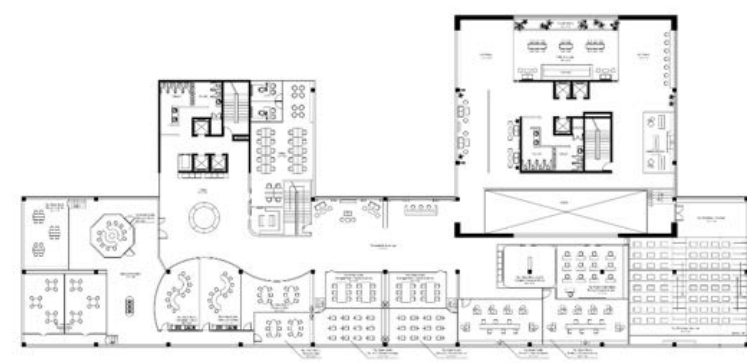

Gambar 10. Layout Ganara (Sumber: Desy Lestary, 2018)

\section{Konsep Desain}

Melalui analisis data yang telah dikumpulkan, maka dapat disimpulkan citra yang mampu mewakili Ganara Art School secara keseluruhan yaitu Artistik, Dinamis, Edukatif dan Modern. Maka dari itu citra yang ingin ditampilkan pada perancangan desain interior Ganara Art School adalah sebuah sekolah seni yang atraktif dan interaktif, bukan hanya menjadi sebuah wadah bagi masyarakat untuk dapat menyalurkan ekspresi seni dan imajinasi kedalam sebuah karya namun juga memberikan edukasi seni kepada 
masyarakat dengan desain yang atraktif dan modern.

Sehingga gaya yang akan diterapkan pada perancangan Ganara Art School adalah "Modern". Konsep gaya Modern mencerminkan perkembangan karya seni rupa kontemporer dan mengikuti perkembangan zaman. Sehingga ruang didesain dengan permainan bentuk minimalis. Penggunaan material dan warna yang minim dan tidak mencolok menciptakan ruangan yang nyaman untuk beraktivitas dan berhubungan dengan karya seni.

Konsep tema yang diangkat didalam perancangan Ganara Art School ditentukan slogan utama yaitu " $a$ haven for art enthusiasts" yang memikiki arti "suatu tempat kediaman bagi penggemar seni". Menurut Lowfeld (1982) Seni merupakan " $a$ means of expression", seni juga memiliki fungsi sebagai media komunikasi yang diwujudkan dalam karya serta sebagai media bermain yang melibatkan imajinasi, pikiran dan perasaan Tumurang (2006:31).

Maka tema yang akan diangkat kedalam perancangan Ganara Art School adalah 'Explore and find Serenity'. Explore memiliki arti menjelajahi atau mencari sesuatu untuk tujuan tertentu, dan Serenity memiliki arti calm and peaceful situation. Explore Imagination merupakan kata kunci utama dalam konsep perancangan dengan permainan bentuk eksploratif, diadopsi dari prototipe bentuk alam yaitu pohon, lembah dan goa yang diimplementasikan ke dalam elemen interior dengan gaya modern serta penggunaan material dan warna yang minim sehingga pengguna ruang dapat bebas berimajinasi tanpa diinterupsi oleh warna dan material yang mencolok dari desain ruang tersebut.

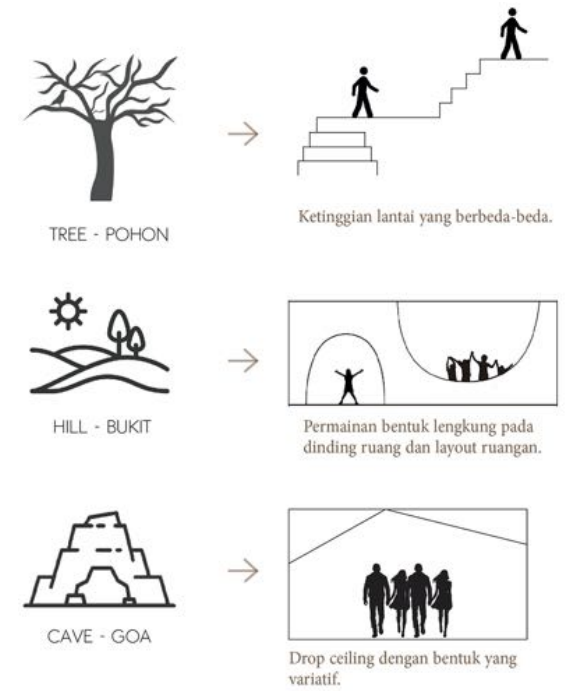

Gambar 11. Prototipe dan Implementasi Desain (Sumber: Desy Lestary, 2018)

Seluruh material elemen pembentuk ruang didominasi dengan raw-material seperti kayu, concrete dan iron. Warna yang digunakan pada keseluruhan ruang adalah warna-warna natural earth-tone yang hangat seperti coklat, abu dan monochrome. Pada area anak-anak, warna 
yang digunakan akan lebih cerah sedangkan pada area dewasa akan lebih gelap.
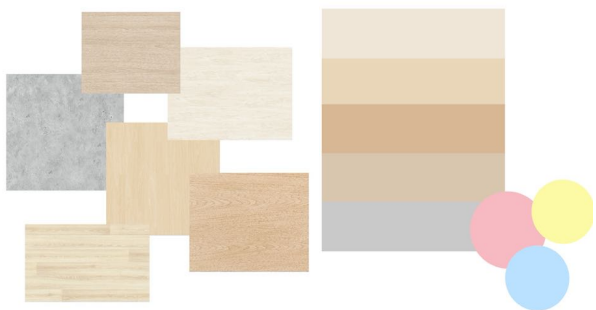

Gambar 12. Skema Material dan Warna (Sumber: Desy Lestary, 2018)

\section{Visualiasi Akhir}

Berikut adalah visualisasi akhir dari perancanan interior Ganara Art School yang meliputi 3 area khusus yaitu Resepsionis \& Waiting area, Ganara Art Studio (anak-anak) meluputi ruang studio menggambar dan melukis, Ganara Art Space (remaja dan dewasa) meliputi ruang studio menggambar dan melukis dan Café \& Lounge area yang berhubungan dengan Art Gallery.

1. Resepsionis dan Waiting Area

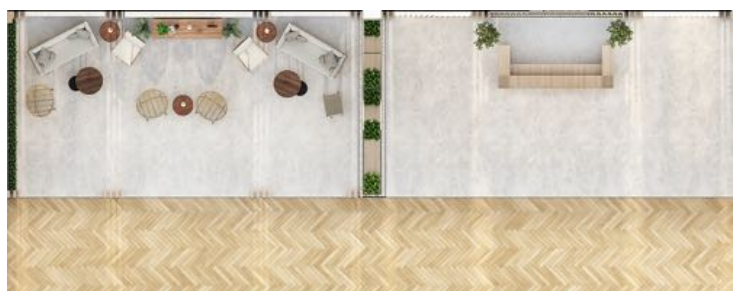

Gambar 13. Layout Resepsionis dan Waiting Area (Sumber: Desy Lestary, 2018)

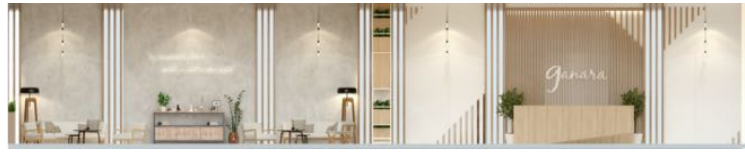

Gambar 14. Tampak Resepsionis dan Waiting Area (Sumber: Desy Lestary, 2018)

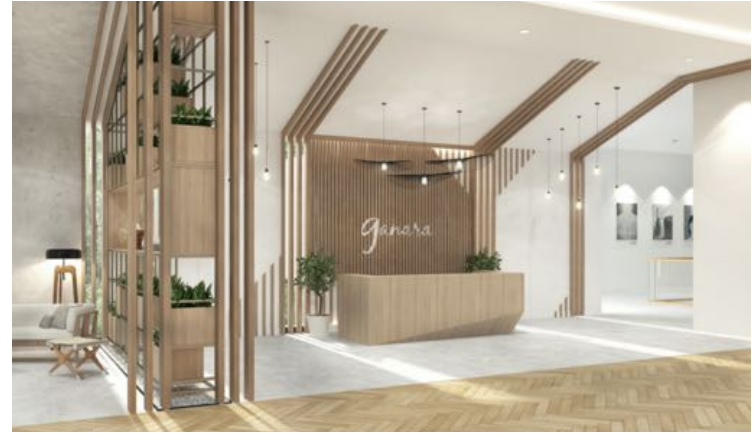

Gambar 15. Perspektif Resepsionis (Sumber: Desy Lestary, 2018)

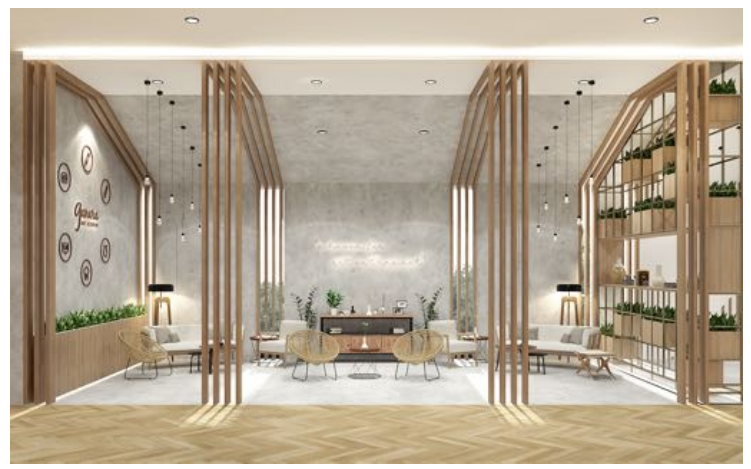

Gambar 16. Perspektif 1Waiting Area (Sumber: Desy Lestary, 2018)

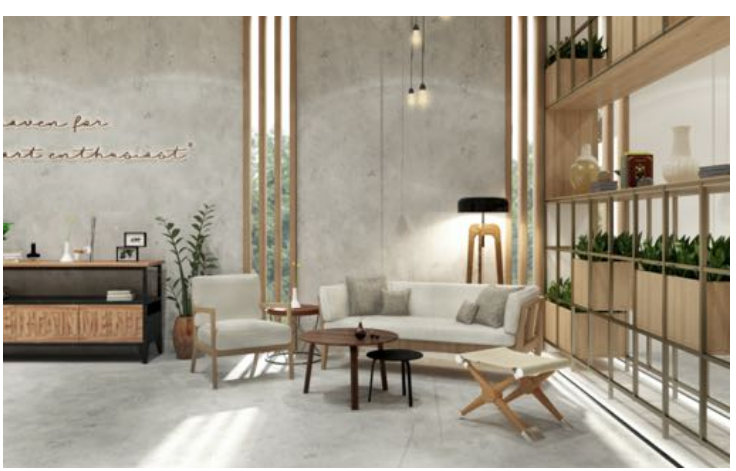

Gambar 17. Perspektif 2 Waiting Area (Sumber: Desy Lestary, 2018)

2. Ganara Art Studio (Anak-anak)

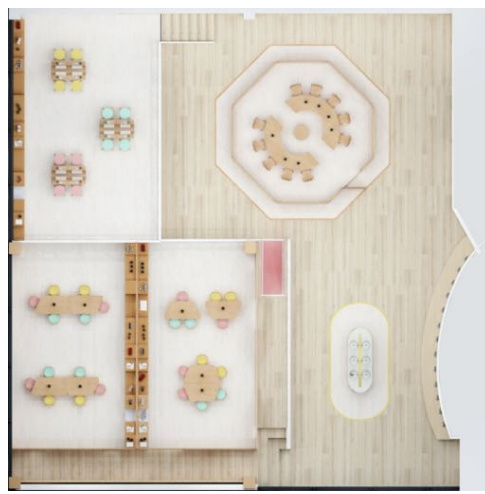

Gambar 18. Layout Ganara Art Studio (Sumber: Desy Lestary, 2018) 


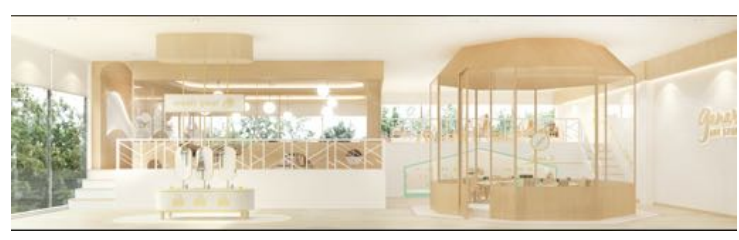

Gambar 19. Perspektif 1 Ganara Art Studio

(Sumber: Desy Lestary, 2018)

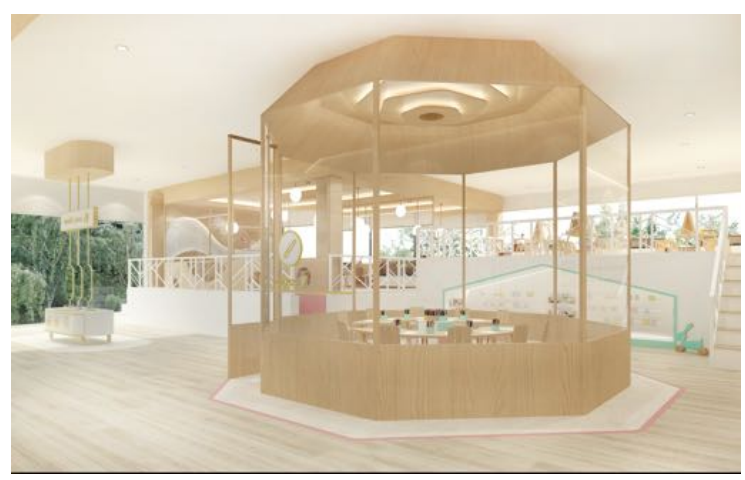

Gambar 20. Perspektif 2 Ganara Art Studio (Sumber: Desy Lestary, 2018)

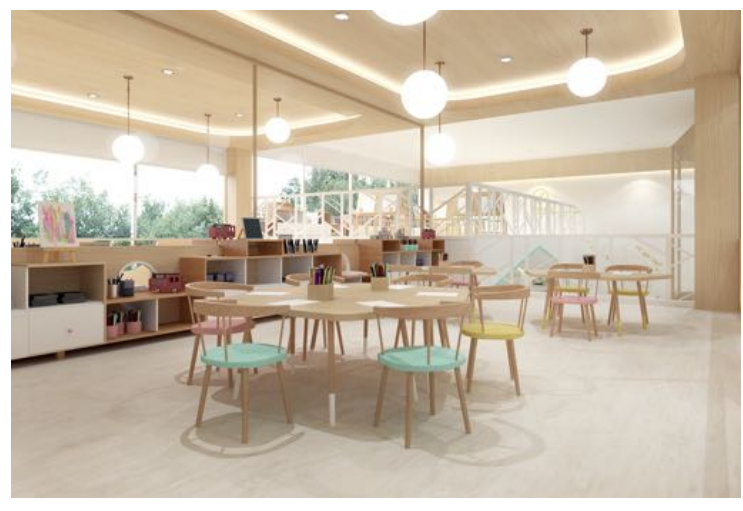

Gambar 21. Perspektif Rg. Studio Menggambar (Sumber: Desy Lestary, 2018)

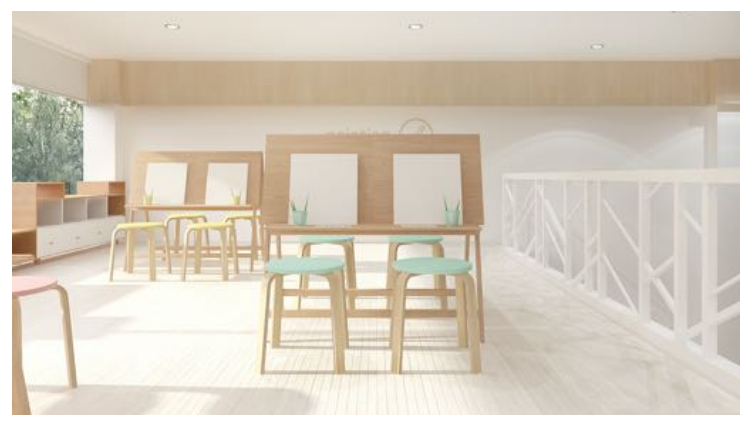

Gambar 22. Perspektif Rg. Studio Melukis (Sumber: Desy Lestary, 2018)

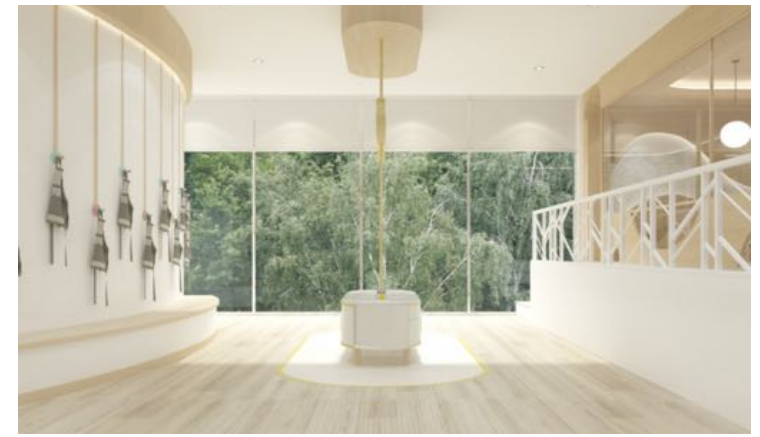

Gambar 23. Perspektif 3 Ganara Art Studio (Sumber: Desy Lestary, 2018)

\section{Ganara Art Space (Remaja \& Dewasa)}

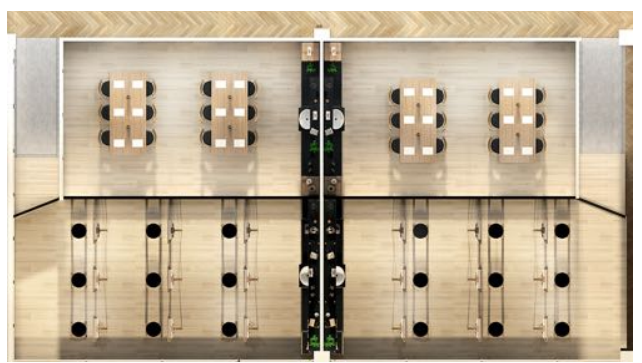

Gambar 24. Layout Ganara Art Space (Sumber: Desy Lestary, 2018)

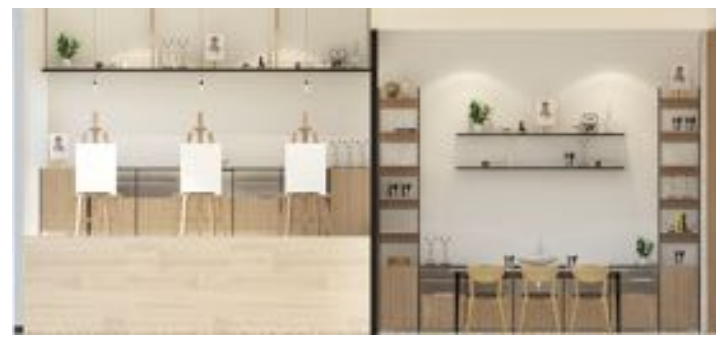

Gambar 25. Potongan Ganara Art Space (Sumber: Desy Lestary, 2018

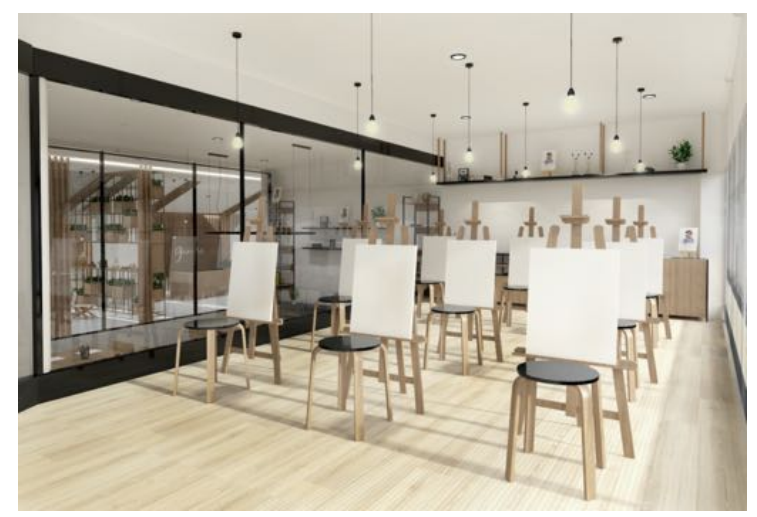

Gambar 26. Perspektif Rg. Studio Melukis (Sumber: Desy Lestary, 2018) 


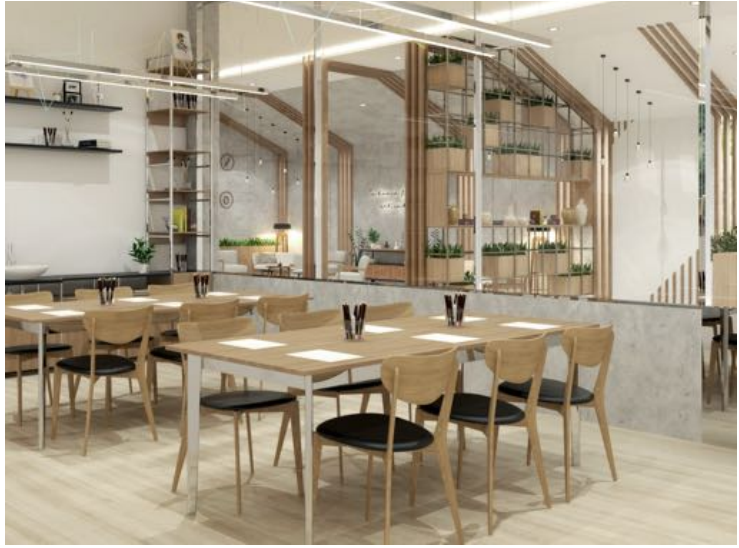

Gambar 27. Perspektif Rg. Studio Menggambar (Sumber: Desy Lestary, 2018)

\section{Café and Lounge Area}

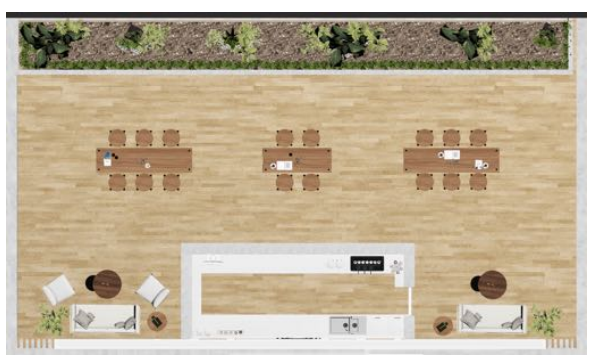

Gambar 28. Layout Café and Lounge Area (Sumber: Desy Lestary, 2018)

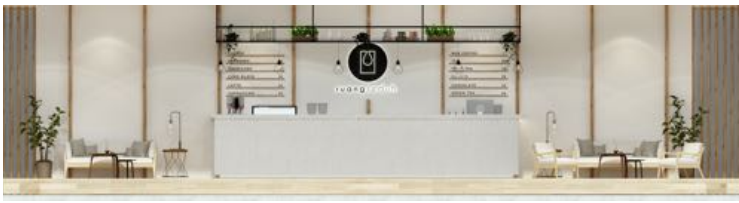

Gambar 29. Potongan Café and Lounge Area (Sumber: Desy Lestary, 2018)

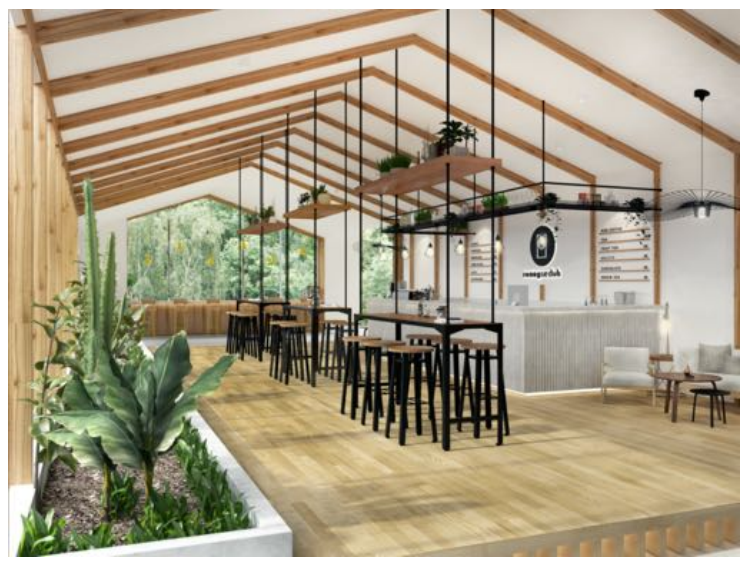

Gambar 30. Perspektif 1 Café and Lounge Area (Sumber: Desy Lestary, 2018)

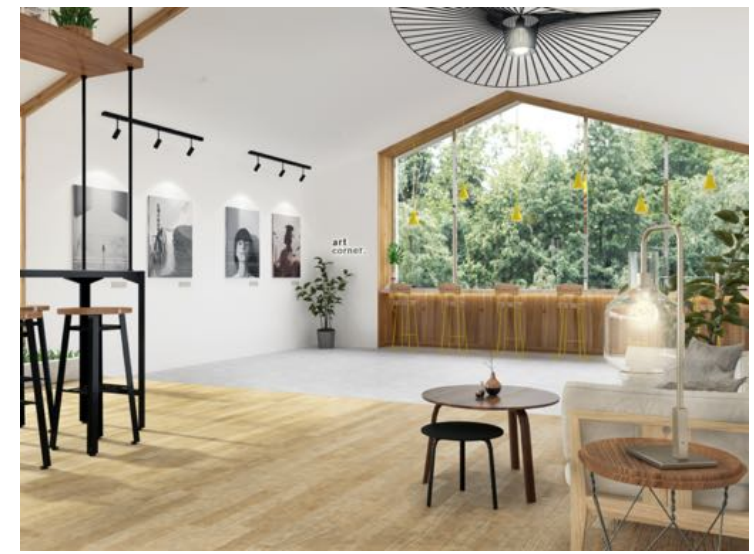

Gambar 31. Perspektif 2 Café and Lounge Area (Sumber: Desy Lestary, 2018)

\section{SIMPULAN}

Ganara merupakan salah satu sekolah seni di Jakarta. Konsep desain yang diangkat dalam perancangan ini adalah Explore and Find Serenity yang mengutamakan permainan bentuyk prototipe bentuk alam dan diimplementasikan dengan gaya modern. Perancangan juga bertujuan untuk memenuhi kebutuhan aktivitas dan fasilitas sehingga dapat berjalan dengan efektif dan efisien serta mencerminkan citra lembaga.

\section{DAFTAR PUSTAKA}

Central Building Research Institute Roorkee. 1986. School Buildings for AfroAsian Countries. New Delhi: Tata McGrawhill Publishing Company Limited.

Chiara, Joseph De dan Michael J. Cr. 1980.

Time-saver Standards for Building Type. the University of Michigan: McGraw-Hill. 
Chilvers, Ian. 2015. The Oxford Dictionary of Art and Artist. United Kingdom.

Edson, Lee. 1987. Cara Kita Belajar. Jakarta:

Tirta Pustaka Jaya.

Herawati, Ida Siti dan Iriaji. 1998.

Pendidikan Seni Rupa. Jakarta:

Departemen Pendidikan dan

Kebudayaan Dirjen Pendidikan Tinggi.

Hetty, Tumurang. 2006. Pembelajaran

Kreativitas Seni Anak Sekolah Dasar

Jakarta. Jakarta: Depdiknas.

Kilmer, Rosemary. 2014. Designing Interiors. $2^{\text {nd }}$ Edition. New Jersey: Wilson Learning.

Nurhadiat, Dedi. 2004. Pendidikan Seni

Rupa: Seni Rupa 2. Jakarta: PT. Grasindo.

Pamadhi, Hajar. 2012. Pendidikan Seni. Yogyakarta: UNY Press.

Panero, Julius dan Martin Zelnik. 2003. Dimensi Manusia dan Ruang Interior. Jakarta: Erlangga.

Tangoro, Dwi, 2006. Utilitas Bangunan. Jakarta: UI-Press.

Wahyu, S. A. A. 2006. Manajemen Sarana dan Prasarana Pendidikan. Jakarta: CV. Multi Karya Mulia.

Westley, Hester dkk. 2010. From Floor To Sky: The Experience of The Art School Studio. London: A\&C Publisher Limited.
Winkel, W.S. 2004. Psikologi Pengajaran. Yogyakarta: Media Abadi. 